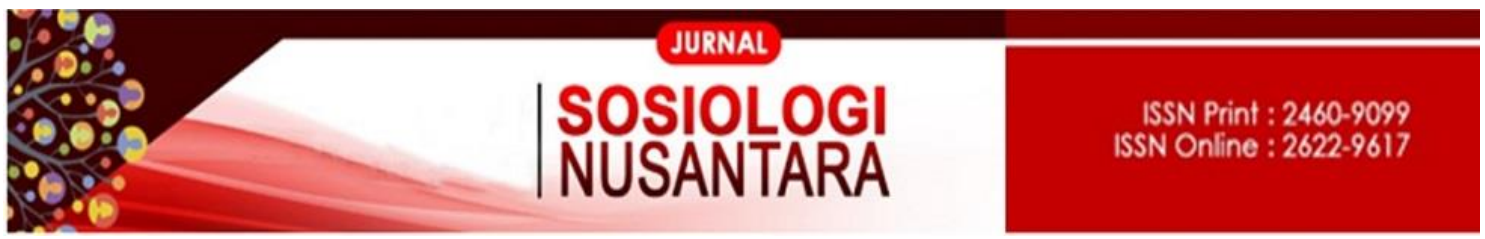

DOI ://doi.org/10.33369/jsn.5.1.22-42

\title{
ANALISIS SOSIAL-EKONOMI FAKTOR PENYEBAB PERKAWINAN ANAK DI BENGKULU: \\ DALAM PERSPEKTIF MASYARAKAT DAN PEMERINTAH (Studi Kasus di Kabupaten Seluma)
}

\section{ANALYSIS OF SOCIO-ECONOMIC DETERMINANTS OF CHILD MARRIAGE IN BENGKULU: IN GOVERNMENT AND SOCIETY PERSPECTIVE (Case Study Child Marriage in Seluma Regency)}

\author{
Heri Sunaryanto \\ hsunaryanto55@gmail.com
}

Fakultas Ilmu Sosial dan Ilmu Politik, Universitas Bengkulu

\begin{abstract}
Abstrak
Penelitian analisis faktor penyebab pernikahan anak di Bengkulu mengambil kasus di kabupaten Seluma merupakan respon terhadap masih tingginya perkawinan anak usia 10-14 tahun di Provinsi Bengkulu (6,3\%) yang merupakan angka tertinggi nomor 6 di Indonesia. Penelitian ini merupakan penelitian deskriptif kualitatif melibatkan tokoh masyarakat baik formal maupun informal menggunakan teknik Focus Group Discussion (FGD).Tujuan utama dari penelitian pernikahan anak ini adalah melakukan identifikasi dan analisis terhadap faktor-faktor sosial, budaya, ekonomi dan agama yang mendorong terjadinya perkawinan anak di Seluma. Hasil penelitian menunjukan bahwa menurut para pemangku kepentingan beberapa faktor yang berkontribusi terhadap perkawinan anak di Kabupaten Seluma antara lain : lingkungan sosial, kemiskinan, wawasan orangtua, kearifan budaya, dan kemudahan akses internet (social media). Sedangkan terkait dengan kebijakan terhadap upaya pencegahan pernikahan anak yang telah dilakukan masih belum optimal dilakukan oleh institusi yang secara langsung berkaitan dengan eksistensi pernikahan anak di Seluma.Rekomendasi terkait dengan faktortersebut adalah 1).sosialisasi yang lebih intensif terhadap perkawinan anak dan dampaknya, 2).memberikan akses pendidikan yang luas kepada anak anak kelompok keluarga rentan, 3).kerjasama dengan pihak sekolah, lembaga adat, dan lembaga pemerintah terkait untuk melakukan pendidikan kesehatan reproduksi kepada para anakanak untuk tidak melakukan perkawinan usia muda, dan 4).penegakan Undang-Undang Perkawinan yang lebih tegas.
\end{abstract}

Kata Kunci: Pernikahan anak, Diskriptif, Faktor Sosial-ekonomi. 


\begin{abstract}
The main purpose of the study is to identificaty and analysis factors of social, cultural, economic and religious encouraging child marriage in Seluma Regency. The secondary data is used to describe the socio-demographic population of the district Seluma, including teenagers who practice child marriages in the sub-district of Sukaraja as a research area. While the primary data are used to identify and explain the relationship between the factors driving the phenomenon of child marriages. The primary data was obtained through Focus Group Discussion (FGD) that has involve, stakeholders such as, community leaders, religious leaders and parents. This research is descriptive analytic. The results showed that in general the phenomenon of child marriages showed a downward trend and occurs for several reasons, namely social environment, poverty, the knowledge of parents (family), cultural wisdom, and internet access (social media). Inorder to decresing the number of child marriage such recommendations should be address to intensify socialization to child marriage and its impact, provide access to a broad education to children groups of vulnerable families, cooperate with the school, traditional institutions, and government agencies related to education reproductive health to the children not to early marriage, and finally to enforce the marriage act more stringently.
\end{abstract}

Key word: Child marriage, Descriptive, Social-economic factors.

\title{
PENDAHULUAN
}

Perkawinan anak merupakan masalah serius yang dihadapi oleh negara berkembang termasuk Indonesia. Berbagai kajian menyimpulkan perlunya menghentikan perkawinan anak dikarenakan dampaknya yang luar biasa terhadap kemanusiaan khususnya kematian ibu dan bayi. Upaya mengenali faktor penyebab menjadi syarat mutlak guna merumuskan kebijakan strategis pencegahan terhadap perkawinan anak di negara berkembang (ICRW, 2005, Unicef 2001, UNFPA, 2016). Di Bengkulu, angka perkawinan anak diatas rata-rata data nasional dan menduduki nomor 6 (enam) tertinggi se Indonesia (Riskesdas, 2010). Oleh karena itu, perlu kajian komprehensif atas berbagai faktor yang melatarbelakangi perkawinan anak di Bengkulu.Hasil kajian diharapkan dapat menjadi pijakan perumusan model kebijakan dalam rangka untuk menghentikan praktek perkawinan anak.

Lahir, nikah dan mati merupakan tiga kejadian yang dialami hampir semua manusia di dunia, tetapi hanya menikah yang merupakan bagian manusia untuk memilihnya.Hak untuk menikah melekat pada diri setiap individu yang dilindungi oleh norma/aturan sosial sejak zaman Yunani kuno dan juga telah dilindungi oleh the 1948 universal declaration of human right (UDHR) (UNICEF, 2005).Artinya, pernikahan yang dipaksakan jelas melanggar hak asasi manusia. Lebih jauh, meskipun menikah 
adalah hak setiap individu, namun demikian, dalam pelaksanaannya harus mengindahkan aturan-aturan hukum yang berlaku agar legal secara hukum. Legalitas perkawinan juga bertujuan untuk melindungi perkawinan itu sendiri sehingga tujuan perkawinan yang sangat mulia yaitu membentuk suatu keluarga yang bahagia, kekal abadi berdasarkan Ketuhanan Yang Maha Esa dapat terwujud dan bukan sebaliknya penuh konflik dan menyengsarakan kedua belah pihak.Dalam banyak kasus perkawinan anak, perempuan sering menjadi korbannya karena berhubungan dekat dengan nilainilai sosial, budaya dan agama dimana di kebanyakan negara berkembang yang merujuk pada sistem patriarki, kaum perempuan sering dimarginalkan (UNICEF, 2001; Nasrin dan Rahman, 2012)

Fakta pernikahan yang terjadi di belahan dunia termasuk di Indonesia dalam derajat tertentu telah menabrak rambu-rambu hak asasi manusia dan aturan perundangan yang dimiliki oleh banyak negara.Sebut saja perkawinan anak yang di Indonesia sering disebut "perkawinan dini”. Dari laporan UNICEF (2005) hasil kajian dibeberapa negara berkembang di Afrika, Asia Selatan-Tenggara, Timur Tengah, dan Amerika Latin menunjukan masih tingginya angka perkawinan anak ( antara 50-80 persen ). Laporan yang dirilis oleh World Fertility Policy (WFP) tahun 2012 menegaskan bahwa sepertiga perempuan di dunia telah melakukan pernikahan sebelum usia 18 tahun.

Persoalan pernikahan anak juga terjadi di Indonesia bahkan menjadi persolan yang kompleks karena berdampak pada berbagai parameter kependudukan yang telah menjadi pusat perhatian pemerintah saat ini seperti kematian bayi, kematian ibu, perceraian, KDRT dan angka putus sekolah (Droup Out) (Plan Indonesia, 2012). Sebagaimana telah disepakati oleh dunia soal usia perkawinan anak, Indonesia juga menegaskan dalam beberapa undang-undang terkait perkawinan anak. Undang-undang No 1 tahun 1974 tentang Perkawinan Bab 2 pasal 7 ayat 1 berbunyi "Perkawinan hanya diijinkan jika pihak laki-laki sudah mencapai umur 19 tahun tahun dan pihak perempuan sudah mencapai umur 16 tahun". Selanjutnya UU No.23 tahun 2002 menyatakan usia dibawah 18 tahun dikategorikan sebagai anak. Pasal 26 menyatakan bahwa orang tua berkewajiban dan bertanggung jawab untuk mencegah terjadinya perkawinan anak.Undang-undang Nomor 1 tahun 1974, menjadi salah satu pemicu tingginya angka pernikahan anak di Indonesia dilihat dari batasan umur yang telah disepakati oleh UNICEF. 
Fakta perkawinan anak di Indonesia menurut beberapa laporan juga cukup memprihatinkan Menurut laporan International Centre for Research on Women (ICRW) bahwa Indonesia termasuk negara dengan persentase pernikahan usia muda tinggi didunia (ranking 37 dari 73 negara dengan pernikahan dini tertinggi) dan tertinggi kedua di ASEAN setelah Kamboja (ICRW,2014). Beberapa hasil penelitian memperkuat indikasi masih kuatnya perkawinan anak.Yang ditunjukan melalui data bahwa masyarakat Indonesia terutama yang tinggal dipedesaan masih cukup kuat memegang nilai-nilai sosial keagamaan yang membenarkan tradisi perkawinan muda (Baker, 2016).

Selanjutnya, Plan Indonesia (2012), organisasi kemanusiaan yang fokus pada perlindungan dan pemberdayaan anak, menyampaikan hasil temuannya mengenai pernikahan dini di 8 Kabupaten di Indonesia pada 2011 (Indramayu (Jawa Barat); Grobogan dan Rembang (Jawa Tengah); Tabanan (Bali); Dompu (NTB); serta Timor Tengah Selatan, Sikka, dan Lembata (NTT). Plan Indonesia mencatat ada 33,5 persen anak usia 13-18 tahun pernah menikah, dan mereka menikah pada rata-rata usia 15-16 tahun. Data ini tak jauh berbeda dengan temuan Bappenas tahun 2008 bahwa 34,5 persen dari 2.049.000 perkawinan di tahun 2008 adalah perkawinan anak. (Bappenas, 2008).Kecenderungan ini menunjukan bahwa satu dari enam anak perempuan menikah sebelum berusia 18 tahun yang jumlahnya mencapai 340.000 setiap tahun. Lebih dari itu ditengarai ada 50.000 anak perempuan yang menikah sebelum usia 15 tahun. Bagi anak yang menikah, menurut Gunill Olsson selaku Kepala Perwakilan UNICEF Indonesia, setiap anak yang menikah, mereka telah kehilangan masa kanak-kanaknya," (Unicef Indonesia, 2015).

Potret perkawinan anak di provinsi Bengkulu tidak kalah buramnya dengan gambaran perkawinan anak umumnya di Indonesia. Tingkat perkawinan anak di Bengkulu tergolong tinggi dibandingkan dengan provinsi lainnya di Indonesia. Dari hasil Riset Kesehatan Dasar (Riskedas) 2010, Usia perkawinan pertama perempuan kelompok umur 15-19 mencapai 45,9 persen lebih tinggi dari angka rata-rata nasional (41,9 persen). Bengkulu menempati urutan ke enam di Indonesia untuk kasus perkawinan anak kelompok umur 10-14. Data yang ditunjukan hasil Riskesdas 2010 bahwa usia perkawinan pertama kelompok umur 10-14 tahun tertinggi nomor 6 se Indonesia, yaitu 6.3\%, rata-rata Indonesia : 4,8 \%. (Kalsel (9\%); Jabar (7,5\%); Kaltim 
dan Kalteng (7 \%) dan Banten (6,5\%) (Riskesdas 2010).Jika diperbandingkan antar kabupaten di Bengkulu, tingginya angka perkawinan anak berbeda-beda dan yang tergolong tinggi adalah Kabupaten Seluma, Muko-Muko dan Bengkulu Tengah.

Tabel 1. Persentase Perempuan yang Pernah Kawin Berumur 10 Tahun Ke Atas menurut Kabupaten/Kota dan Umur Perkawinan Pertama, 2016

\begin{tabular}{lccccc}
\hline Kabupaten/Kota & $\mathbf{1 6}$ & $\mathbf{1 7 - 1 8}$ & $\mathbf{1 9} \mathbf{- 2 0}$ & $\mathbf{2 1 +}$ & Rata-rata \\
\hline-1 & -2 & -3 & -4 & -5 & -6 \\
\hline 01. Bengkulu Selatan & 14,11 & 24,21 & 26,13 & 35,55 & 19,93 \\
\hline 02. Rejang Lebong & 13,48 & 26,80 & 27,07 & 32,66 & 20,02 \\
\hline 03. Bengkulu Utara & 15,02 & 22,32 & 29,79 & 32,86 & 19,81 \\
\hline 04. Kaur & 14,85 & 24,44 & 25,52 & 35,18 & 19,79 \\
\hline 05. Seluma & 16,25 & 27,26 & 25,11 & 31,38 & 19,53 \\
\hline 06. Mukomuko & 27,53 & 22,92 & 23,24 & 26,32 & 19,01 \\
\hline 07. Lebong & 14,26 & 21,82 & 26,27 & 37,64 & 20,14 \\
\hline 08. Kepahiang & 18,77 & 21,49 & 28,72 & 31,02 & 19,79 \\
\hline 09. Bengkulu Tengah & 22,93 & 27,24 & 17,96 & 31,87 & 19,50 \\
\hline 71. Kota Bengkulu & 13,75 & 13,29 & 20,61 & 52,35 & 21,42 \\
\hline Bengkulu & $\mathbf{1 6 , 4 7}$ & $\mathbf{2 2 , 4 8}$ & $\mathbf{2 5 , 2 3}$ & $\mathbf{3 5 , 8 2}$ & $\mathbf{2 0 , 0 2}$ \\
\hline
\end{tabular}

Sumber: BPS, Susenas 2016

Pada Tabel 1 menunjukan bahwa angka pernikahan anak kelompok umur dibawah 19 tahun di Kabupaten Seluma, menduduki urutan ketiga di provinsi Bengkulu dengan 43,51\% jauh diatas tingkat pernikahan anak di Kota Bengkulu yang hanya $27,04 \%$ (Susenas, 2016). Perkawinan anak lebih marak terjadi di daerah perdesaan dari pada perkotaan.Masyarakat desa lebih dianggap tradisional dimana mereka sangat memegang teguh tradisi dan nilai-nilai lama dibandingkan dengan masyarakat perkotaan yang lebih modern.

Sejauh ini, belum ada penelitian yang menjelaskan secara komprehensif berbagai faktor yang mendorong tingginya angka perkawinan anak di Bengkulu.Beberapa penelitian baik di Indonesia maupun dunia menunjukkan faktor yang bervariasi yang mendorong terjadinya perkawinan anak. Studi ICRW dan Unicef di Afrika dan Asia Selatan menemukan faktor geografi, agama, budaya dan pendidikan 
menjadi faktor utama yang melatarbelakangi terjadinya perkawinan anak (ICRW, 2005, Unicef, 2005; Nasrin dan Rahman, 2012). Untuk konteks Indonesia merujuk hasil seminar tentang Perkawinan Anak yang didselenggarakan oleh Plan Indonesia dan PPK UGM menyimpulkan ada beberapa faktor dominan yang mendorong tingginya angka perkawinan anak yaitu perilaku seksual dan kehamilan tak dikehendaki, tradisi/budaya, rendahnya pengetahuan seksualitas atau kespro, rendahnya pendidikan orang tua, serta kondisi sosio-ekonomi, kharakteristik wilayah dan geografis, dan lemahnya penegakkan hukum. (Ariefuddin, 2016).

Lebih jauh, hasil penelitian di Afrika, Asia Selatan, Timur Tengah maupun di Indonesia menjelaskan bahwa perkawinan anak lebih banyak menimpa anak-anak perempuan dari pada anak laki-laki. Oleh karena ini perkawinan anak lebih merupakan refleksi dari ketidaksetaraan dan ketidakadilan gender dan dianggap telah melanggar HAM (Unicef, 2005).

Belum jelasnya faktor dominan yang mendorong tingginya perkawinan anak di Kabupaten Seluma inilah yang mendorong penelitian ini menjadi penting dan strategis untuk dilakukan sehingga dengan ditemukenali faktor dominan tersebut akan dirumuskan model kebijakan strategis untuk menghentikan parktek pernikahan anak di Kabupaten Seluma. Mengacu pada latarbelakang tingginya angka perkawinan anak di provinsi Bengkulu, khususnya kabupaten Seluma, permasalah utama penelitian ini adalah faktor-faktor dominan apa saja yang mendorong/berkontribusi terhadap tingginya perkawinan anak di Kabupaten Seluma.Secara umum penelitian ini bertujuan untuk mengidentifikasi dan menganalisis faktor-faktor sosial-budaya yang dominan berkontribusi terhadap tingginya angka perkawinan anak di Kabupaten Seluma.

Pandangan masyarakat Bengkulu pada dasarnya beragam atas realitas perkawinan anak.Masih tingginya angka perkawinan anak di masyarakat Bengkulu, menunjukan bahwa realitas sosial ini dianggap hal yang biasa.Meski demikian tidak sedikit masyarakat yang cenderung untuk menghindari atau menolak praktek perkawinan dengan berbagai pertimbangan seperti si anak masih ingin melanjutkan sekolah, dianggap belum dewasa, dan si anak belum ingin menikah. Dalam rangka menjelaskan perkawinan anak sebagai tindakan sosial akan lebih bijak bila meletakan praktek perkawinan anak kedalam perspektif mikro seperti yang dijelaskan oleh Parson (voluntarism idea) dan Weber (action theory) dimana individu merupakan aktor yang 
bebas, aktif dan kreatif dalam pengambilan keputusan subyektif terhadap tindakan sosialnya (Ritzer dalam Alimandan, 1985, Hagedorn, 1990:18-19).

Pada dasarnya, perkawinan anak lebih merupakan akumulasi dampak dari berbagai faktor sosial-budaya yang komplek, termasuk hasil proses sosialisasi nilai yang di masyarakat. Artinya dalam perspektif interpretasi Weber (Hagedorn, 1990: 7-9) perilaku pernikahan anak harus diletakan pada pemahaman dan perilaku sosial masyarakat.Lebih jauh, menurut perspektif interpretatif bahwa perilaku sosial merupakan refleksi dari pikiran seseorang yang diperoleh dari pengetahuan dan pengalaman hidupnya (Blumer dalam Poloma, 2000: 255-65). Oleh karena itu, latar belakang sosial-budaya seseorang menjadi penting dalam memaknai perkawinan anak. Menggali dan mengkaji pemaknaan perkawinan anak dari berbagai status sosial dan latar belakang sosial-budaya masyarakat di Kabupaten Seluma merupakan langkah strategis untuk mengidentifikasi berbagai faktor sebagai upaya merumuskan model komprehensif pencegahan pernikahan anak yang tidak saling menyalahkan antar individu maupun kelompok tapi sebaliknya lebih merupakan solusi yang komprehensif dan bijak.

\section{METODE PENELITIAN}

Studi ini menggunakan pendekatan kualitatif dengan teknik pengumpulan data berupa diskusi kelompok terfokus (FGD-Focuse Group Discussion) dan wawancara mendalam (depth interview). Diskusi kelompok terfokus dan wawancara mendalam dilakukan agar peneliti dapat memahami lebih dalam sudut pandang informan penelitian serta latar belakang konteks sosial budaya mereka terkait dengan masalah perkawinan anak. Lebih jauh teknik ini digunakan untuk menarik kesimpulan terhadap maknamakna intersubyektif yang sulit dipahami oleh peneliti karena ketidaktahuan peneliti terhadap apa yang melatarbelakngi pemaknaan terhadap perkawinan anak tersebut dan juga untuk menghindari subyektifitas peneliti terhadap simbol pernikahan anak.

Cakupan wilayah penelitian ini adalah Kabupaten Seluma.Penelitian ini merupakan penelitian kualitatif dengan metode deskriptif analitik. Adapun sumber data dalam penelitian ini adalah keluarga korban, tokoh masyarakat, tokoh agama dan pemangku kepentingan di Kabupaten Seluma.Mereka dipilih dengan pertimbangan memiliki pengetahuan yang baik terhadap praktek pernikahan anak yang terjadi di 
wilayahnya.Diskusi kelompok terfokus (FGD) dibagi kedalam dua kelompok.Kelompok pertama diikuti oleh tokoh masyarakat, agama dan keluarga korban yang tinggal di Kecamatan Sukaraja, Kabupaten Seluma.Informan dipilih atas dasar kriteria memiliki pengetahuan dan atau pengalaman atas praktek perkawinan anak diwilayahnya.Kecamatan Sukaraja dipilih karena merupakan wilayah dengan praktek perkawinan anak yang cukup tinggi.Sedangkan kelompok kedua diikuti oleh perwakilan dari Organisasi Pemerintah Daerah (OPD) karena memfokuskan diskusi pada permasalahan pernikahan anak. OPD yang dilibatkan antara lain Dinas Pendidikan, Dinas Kependudukan, Dinas Sosial, BPS, Bappeda, Kantor Kementrian Agama, Dinas Kesehatan, dan Lembaga Adat selingkung Kabupaten Seluma.

Berbasis ketersediaan data dan informasi yang diperoleh selama pelaksanaan penelitian, dimungkinkan penyusunan data dan analisis variasi antar Kecamatan di Kabupaten Seluma. Informasi/data dari lapangan yang berhasil dikumpulkan dianalisis dan disajikan menggunakan metode Miles dan Huberman yaitu melakukan reduksi, display dan verifikasi terhadap informasi yang diperoleh serta teknik Trianggulasi (Bungi, 2005). Reduksi data adalah pengelompokan data sesuai dengan kharakteristik variabel dari tujuan penelitian untuk menggambarkan kondisi eksisting perkawinan anak di Kabupaten Seluma. Selanjutnya data dan informasi akan dianalisis dengan melakukan crosschek dengan penelitian terdahulu. Selain itu juga dianalisis dengan teori yang menjelaskan hubungan antar beberapa perkawinan anak dengan faktor terkait.

\section{Karakteristik Sosial-Demografi}

Seluma merupakan kabupaten hasil pemekeran tahun 2003 dari Kabupaten induk Bengkulu Selatan. Tahun 2017, menurut kantor BPS Seluma, jumlah penduduk mencapai 189.874 jiwa, yang terdiri dari 97481 laki-laki dan 92393 perempuan. Sebagai kabupaten baru kondisi sosial ekonomi masyarakat relatif masih tertinggal dengan tingkat kemiskinan penduduk menduduki peringkat kedua setelah Kabupaten Kaur yaitu 20,67 persen. Sumber penghidupan masyarakat 70 persen bekerja disektor pertanian.Tingkat pendidikan masyarakat masih relatif rendah dimana rata-rata lama sekolah masih sekitar 8 tahun (Kementrian Pendidikan dan Kebudayaan, 2016).

Selama tahun 2017 telah terjadi 1907 pernikahan di Seluma. Usia Perkawinan Pertama di Kabupaten Seluma adalah 18,64 tahun. Angka ini lebih rendah dari rata-rata 
Provinsi Bengkulu yang berada pada 19,64 tahun (Susenas, 2016). Dalam banyak kasus pernikahan anak terjadi pada perempuan dibandingkan dengan laki-laki. Data menunjukan anak perempuan yang usia kawin pertamanya dibawah umur 21 mencapai 64,64 persen, jauh lebih tinggi dibandingkan usia kawin pertama pada anak laki-laki yang hanya 18,09 persen (Pendataan Keluarga, BKKBN, 2015).

Masyarakat kabupaten Seluma sangat majemuk terdiri dari berbagai macam suku,disamping suku asli Sraway yang mayoritas terdapat juga suku Jawa, Bali, Bugis, Batak dan Padang yang hidup berdampingan, membaur dengan penduduk asli secara rukun dan damai. Menurut data BPS tahun 2017, meskipun beberapa penduduk memeluk agama lain seperti Kristen Katolik, Protestan, Hindu, namun mayoritas penduduk (98,90 persen) memeluk agama Islam. Sehingga, tidak mengherankan bila sistem patriarki masih dominan dan kuat dikalangan masyarakat Seluma.Budaya patriarki ini ditengarangi menjadi salah satu hal yang melatarbelakangi terjadi praktek pernikahan anak yang cukup tinggi di Seluma.

\section{Penyebab Pernikahan Anak}

Informasi terkait dengan latarbelakang pernikahan anak di Sukaraja dilakukan menggunakan metode Focus Group Discustion (FGD) dan wawancara mendalam (Depth Interview).Kedua metode ini dimaksudkan untuk mendapat informasi yang lebih fokus dan mendalam terhadap praktek perkawinan anak di Kabupaten Seluma baik dari latarbelakang ekonomi, sosial dan budaya. Metode ini juga menghindari informasi yang bersifat subyektif dan bias terhadap pernikahan anak yang terjadi karena setiap faktor yang diungkapkan akan mendapat verifikasi dari para nara sumber lainnya yang secara teoritik mereka lebih memahami kondisi dan situasi yang ada di masyarakat. Beberapa latarbelakang sosial-ekonomi yang dapat diidentifikasi melalui diskusi kelompok dan wawancara mendalam dengan para tokoh formal pemerintahan, tokoh masyarakat dan agama, tokoh adat, orang tua pelaku pernikahan dini.

\section{a. Stigma Perawan Tua}

Dalam banyak kajian terkait penikahan anak di negara berkembang, ada hubungan yang kuat antara faktor nilai-nilai sosial keagamaan yang dipegang oleh masyarakat dengan fenomena pernikahan anak (UNICEF, 2001; Nasrin dan Rahman, 2012). Di Sukaraja praktek perkawinan anak bukanlah sesuatu yang baru tapi fenomena ini sudah terjadi dan menjadi warisan nenek moyang mereka. Ada beberapa 
pertimbangan terkait dengan nilai-nilai sosial-budaya yang masih eksis sampai hari ini.Pertama, bahwa bagi masyarakat di Kabupaten Seluma, perkawinan adalah sebuah keniscayaan setiap manusia yang normal. Artinya bahwa setiap laki-laki atau perempuan pasti melaksanakan perkawinan. Perkawinan tidak terikat dengan umur tertentu seperti bahwa menikah harus pada umur dewasa sebagaimana yang diatur dalam UU Perkawinan tahun 1974. Faktor kesepakatan kedua belah pihak lebih menjadi rujukan/dasar terjadinya pernikahan.Apabila kedua belah pihak (orangtua) setuju maka perkawinan bisa dilaksanakan meskipun umur mereka masih dibawah 16 tahun. Artinya bahwa dari perspektif masyarakat umur anak untuk dapat dinikahkan tidak tergantung berapapun usianya akan tetapi yang menjadi patokan adalah apakah anak tersebut sudah mengalami menstruasi atau belum. Menstruasi dipahami oleh masyarakat sebagai simbol bahwa anak sudah masuk usia dewasa (akil balig) sebagai petunjuk bahwa anak sudah dapat dinikahkan berapapun usianya.

Ketakutan keluarga terhadap cap (labelling) yang diberikan oleh masyarakat terhadap anak gadis yang tidak kunjung menikah menjadi salah satu faktor pendorong beberapa orang tua untuk segera menikahkan anaknya. "Perawan tua" sungguh menjadi stigma bagi keluarga di masyarakat perdesaan di Seluma. "Perawan tua" adalah status yang dikenakan kepada seorang gadis yang sudah mengalami menstruasi dan cukup umur akan tetapi belum menemukan jodoh hidupnya untuk menjadi pasangannya. Anehnya stigma ini tidak berlaku bagi kaum laki-laki.

Penjelasan terhadap fenomena ini tentu saja tidak dapat dipisahkan dengan sistem keluarga yang sering disebut sistem Patrilineal (Patrilineal Descent) dimana memposisikan laki-laki diatas perempuan dalam peran sosial (Gee, 1994: 321).Dalam sistem ini perempuan sering dikorbankan untuk kepentingan laki-laki karena laki-laki secara sosiologis dalam sistem patrilineal memegang otoritas yang lebih tinggi dan menjadi penanggungjawab keluarga (Kepala Keluarga).Beban yang lebih berat inilah yang mendorong laki-laki harus kuat (superior) sehingga untuk kepentingan ini laki-laki mendapat prioritas dalam banyak hal dan peran dimasyarakat.Sebagaimana diketahui bahwa laki-laki bertanggungjawab dalam urusan publik dan perempuan dalam urusan domestik.Sebagai contoh dalam urusan pendidikan, pada keluarga yang miskin prioritas sekolah menjadi hak dan tanggungjawab laki-laki meskipun secara kualitas perempuan lebih pintar dan bersemangat untuk sekolah. 
Situasi sosial seperti inilah yang ikut mendorong terjadinya pernikahan anak khususnya pada anak perempuan.Fakta yang terjadi dilapangan adalah ketika seorang anak perempuan sudah mengalami menstruasi, maka secara sosiologis dimaknai bahwa anak perempuan tersebut sudah dewasa meskipun umurnya masih anak-anak.Akan tetapi tidak semua wanita yang sudah mengalami menstruasi dinegasi sebagai "perawan tua".Stigma "perawan tua" pada umumnya dikenakan hanya pada anak gadis yg sudah mengalami menstruasi tetapi tidak sedang sekolah.Status sekolah yang disandang seorang gadis dipahami oleh masyarakat desa umumnya di kabupaten Seluma merupakan bagian dari kewajiban seorang anak dan simbol tindakan berbakti pada keluarga.

Dari hasil diskusi dengan informan disampaikan bahwa para orangtua desa menilai seorang anak gadis yang tidak sekolah dianggap tidak memiliki beban tanggungjawab atau tidak bekerja. Dari pada hanya duduk-duduk dirumah dan keluyuran (beraktifitas diluar rumah) yang tidak jelas tujuan hidupnya, maka apabila anak tersebut ada yang melamar atau sudah dekat dengan seorang laki-laki, tidak segan segan orangtua untuk menikahkan. Tidak ada kekhawatiran atau ketakutan sosial, mengingat nilai-nilai sosial budaya yang ada sungguh tidak mempermasalahkan pernikahan anak.Artinya masyarakat yang hadir dalam perhelatan pernikahan anak tersebut tidak mempermasalahkan (menggunjingkan) meskipun pengantinnya masih anak-anak.Hal demikian dianggap sebagai kejadian yang biasa-biasa saja.

Namun demikian apabila anak perempuan masih dalam status sekolah maka orang tua akan menunggu sampai sekolahnya selesai. Bagi masyarakat di Kabupaten Seluma memaksa anak yang sedang sekolah untuk menikah dini akan dihindari kecuali terjadi hal-hal yang memaksa harus dinikahkan seperti hamil diluar nikah. Orang tua dalam derajat tertentu masih menghormati anak yang ingin melanjutkan sekolah. Artinya, apa yang terjadi dilapangan perkawinan anak sebenarnya disadari oleh orang tua untuk dihindari sejauh masih ada pilihan lain. Para orangtua menyadari bahwa perkawinan pada anak yang belum matang dari segi psikologi dan ekonomi pada dasarnya hanya akan menjadi beban orang tua kedua belah pihak sebagai dialami oleh keluarga salah satu nara sumber. Disampaikan bahwa sampai penelitian ini dilaksanakan anak mereka yang sudah menikah tiga tahun yang lalu masih ikut mereka 
dan secara ekonomi juga masih tergantung kedua belah pihak orangtua.Anak mereka hidup bersama dengan orangtua meskipun bergiliran.

\section{b. Kemiskinan}

Kemiskinan disamping dimensinya kompleks ternyata dalam banyak hal menjadi pemicu/pendorong bagi permasalahan sosial lainnya termasuk soal perkawinan anak di Sukaraja.Keluarga miskin selalu dihadapkan pada pilihan yang sulit ketika kondisi ekonominya sangat minim.Berbagai studi tentang dampak kemiskinan terhadap berbagai permasalahan dasar penduduk seperti pendidikan, kesehatan, pekerjaan, dan perumahan telah banyak dijelaskan oleh para ahli (Todaro dan Smith, 2003). Tingkat kemiskinan di Kabupaten Seluma tergolong tinggi yaitu 21,17 persen jauh dari tingkat kemiskinan rata-rata di provinsi Bengkulu (17,16\%) dan nasional $(11,13 \%)$ (BPS, 2016).Kemiskinan penduduk desa di Kabupaten Seluma disamping berdampak pada pemenuhan kebutuhan dasar juga berdampak pada tingginya angka perkawinan anak.

Keterkaitan kemiskinan dengan perkawinan anak pada beberapa keluarga di Kabupaten Seluma lebih dikarenakan ketidakmampuan membiayai sekolah anak perempuan dari pada upaya untuk meringankan beban ekonomi keluarga.Sebagaimana telah disampaikan sebelumnya budaya patriarki dipedesaan Sukaraja masih menjadi orientasi masyarakat dalam pengambilan keputusan berkaitan dengan peran perempuan dan laki-laki.Bagi keluarga tidak mampu biaya untuk menyekolahkan anak bukanlah hal yang mudah. Katakanlah ada beasiswa untuk warga miskin namun sekolah bukan sekedar soal membayar sekolah tapi ada kebutuhan lain yang juga tidak kalah penting dan menjadi satu kesatuan dengan sistem sekolah yaitu, buku, seragam, sepatu dan alatalat kebutuhan pembelajaran lainnya dan transportasi yang itu semua berkaitan dengan uang. Dalam perspektif keluarga miskin, justru kebutuhan seperti itu yang jauh lebih dirasakan berat dibandingkan dengan SPP (Sumbangan Pembangunan Pendidikan) sekolah. Sungguh keluarga tidak ingin anaknya menjadi sasaran olokan (bully) teman teman sekolahnya karena seragam yang lusuh, sepatu yang sudah tidak layak pakai, tas sekolah yang sobek dan seterusnya. Lebih jauh kondisi kemiskinan keluarga membutuhkan sumberdaya manusia yang lebih untuk membantu agar mereka bisa bertahan hidup. Dalam konteks inilah kehadiran anak lebih dibutuhkan untuk membantu 
keluarga melakukan kerja apa saja asal dapat untuk mempertahankan hidup mereka (hosthold strategy)(Wood, 1981).

Kondisi anak perempuan yang tidak sekolah dan kerja serabutan membantu keluarga seringkali menjadi pendorong terjadinya pernikahan anak.Dalam derajat tertentu ini juga terjadi pada pihak keluarga yang punya anak laki laki yang tidak sekolah karena tidak ada biaya dan kesehariannya hanya membantu keluarga di kebun membantu bekerja orang tua. Bedanya pada pihak keluarga yang memiliki anak lakilaki tidak ada kekuatiran akan klaim masyarakat tentang "bujang tua" sementara pada anak perempuan dilekatkan stigma "perawan tua". Anggapan sosial ini juga menjadi salah satu pendorong untuk menyegerakan anak menikah, selain ketidakmampuan ekonomi.

Dapat disimpulkan bahwa keterkaitan kemiskinan dengan pernikahan anak di Kabupaten Seluma lebih dikarenakan dampak kemiskinan terhadap kelanjutan sekolah anak-anak perempuan bukan terkait dengan meringankan beban ekonomi.Faktanya dari hasil FGD (Focus Group Discussion) menunjukan bahwa perkawinan anak masih tetap menjadi beban ekonomi keluarga.Kondisi ekonomi ini diperkuat dengan stigma "perawan tua” yang secara sosiologis juga membebani keluarga.

\section{c. Ketidakpahaman Undang-Undang Perkawinan}

Perkawinan adalah bagian dari siklus hidup manusia. Bagi sebagian besar masyarakat desa, ada kecenderungan memandang perkawinan lebih sebagai adat kepantasan dan tidak berkaitan dengan usia nikah sebagaimana yang diatur dalam Undang-Undang Perkawinan No. 1 tahun 1974. Dari hasil FGD diperoleh penjelasan bahwa memang ada masyarakat yang tidak tahu atau memahami soal Undang-Undang (UU) pernikahan tersebut.Namun demikian itu terjadi pada sebagian kecil orang dan biasanya mereka tinggal dipelosok desa yang jauh dari sentuhan informasi dan sosialisasi. Sebagian besar peserta FGD mereka mengaku tahu dan paham tentang usia pernikahan anak yang direkomendasikan oleh UU Perkawinan.

Mereka yang melakukan perkawinan anak, mengaku tidak melanggar nilai-nilai sosial budaya dan keagamaan.Hal ini bukan soal permisif atau tidak adanya aturan yang ada, namun lebih merupakan warisan nilai sosial budaya dari generasi ke generasi. Para pendahulu mereka pun telah melakukan praktek perkawinan usia anak sejak dulu kala. 
Dalam perspektif interaksi-simbolik, perilaku mereka terhadap perkawinan anak merupakan refleksi pemikiran subyektif sebagai hasil warisan pengalaman dan pengetahun yang diperoleh dari proses interaksi sosial (Ritzer, 2003). Pada keluarga modern, meskipun perkawinan adalah sesuatu yang syah dari tradisi mereka, namun mereka tetap berusaha untuk mematuhi UU Perkawinan. Faktanya sebagai telah didiskripsikan sebelumnya, dimana jumlah mereka yang melakukan perkwinan anak hanya sedikit (kurang dari 1\%) dari pasangan usia subur artinya kasus perkawinan anak di Sukaraja terjadi karena pertimbangan pertimbangan tertentu dimana keluarga melakukannya karena kondisi sosial ekonomi yang memaksa.

Dengan demikian permasalahannya terletak bahwa dari perspektif budaya mereka, pernikahan anak tidak dilarang tetapi juga tidak dianjurkan kecuali dengan situasi dan kondisi yang memang terpaksa. Kebanyakan keluarga dan orang tua masih sangat berharap anak mereka bisa menikah pada usia yang memang sudah matang sehingga mereka benar-benar bisa membangun keluarga mandiri dan layaknya sebuah keluarga yang mapan. Artinya, masyarakat (keluarga) sangat memahami pesan yang terkandung dalam UU Perkawinan bahwa usia menikah anak perempuan minimal 16 tahun dan anak laki-laki 19 tahun. Bahkan dari hasil FGD mereka berharap anaknya bisa menikah pada umur yang lebih matang 20-21 tahun.

\section{d. Kearifan Budaya Lokal}

Kearifan lokal masyarakat yang tersebar di desa-desa dan kampung di kabupaten Seluma yang merupakan gagasan konseptual (social values system ) yang sudah lama hidup dan diakui kebenarannya oleh sebagian besar masyarakat, masih eksis dalam kesadaran masyarakat sampai hari ini (ketika penelitian dilaksanakan). Nilai-nilai sosial ini tidak saja berfungsi dalam mengatur kehidupan masyarakat yang sifatnya sakaral yaitu berhubungan dengan kekuatan spiritual akan tetapi juga eksis dalam perilaku masyarakat di Kabupaten Seluma pada umumnya.

Masyarakat tradisional Seluma memiliki pandangan bahwa menikah muda lebih baik dari pada terjadi perilaku seksual pra-nikah.Nilai budaya yang dipegang oleh masyarakat desa memposisikan pernikahan sebagai jalan keluar untuk mencegah perzinahan yang secara budaya maupun agama sangat dilarang. Dalam perspektif orang tua apabila anak sudah berpacaran serius dan menurut orang tua ke dua anak dipandang 
sama-sama suka, maka menikah merupakan jalan yang bijak secara budaya, lupakan usia. Hal ini semata karena pertimbangan moral sosial dan agama, takut terjadi apa-apa yang dapat menjadi stigma keluarga dan yang bersangkutan.

Meskipun nilai-nilai sosial-budaya permisif terhadap pernikahan anak, namun demikian nilai-nilai sosial-budaya sangat tegas terhadap perilaku hubungan sex pra nikah.Mereka mengecam dan memberi sangsi sosial yang tegas apabila terjadi hubungan pra nikah dan tertangkap tangan oleh warga masyarakat.Tidak saja bersih kampung dan membayar denda adat tetapi kedua pasangan harus dinikahkan senang tidak senang, keluarga setuju tidak setuju karena dianggap telah membawa aib untuk desa dan masyarakat dan harus dibersihkan dengan istilah mereka "cuci kampung". Kalau tidak dilakukan ritual cuci kampung maka dikhawatirkan akan terjadi apa apa (balak) terhadap kehidupan masyarakat atau desa.

Mengantisipasi kejadian seperti itu, maka keluarga akan segera menikahkan anaknya meskipun masih dibawah usia pernikahan menurut UU Perkawinan. Kalau hubungan sosial anak-anak dalam perspektif orangtua dipahami hubungan sudah saling dekat dan keluarga juga sudah saling mengetahui dan tidak saling berkeberatan, maka menikah dalam situasi seperti ini dianggap jalan keluar yang paling baik (kearifan sosial/budaya) mencegah keburukan yang lebih besar.

Kearifan lokal yang lain adalah bahwa jodoh adalah kehendak yang Maha Kuasa dan pantang untuk ditolok. Menolak pemberian yang Maha Kuasa merupakan tindakan yang dilarang oleh nilai-nilai sosial dan agama yang mereka yakini.Kalau memang jodoh sudah datang, maka pantang untuk ditunda. Pemaknaan "jodoh sudah datang" tentu sudut pandang yang subyektif. Dalam kehidupan di mayarakat desa Seluma pemahaman jodoh diterjemahkan apabila kedua anak sudah lama saling mengenal, keluarga sama-sama mengetahui hubungan mereka tidak sebatas pertemanan tapi dimata orang tua sudah dianggap lebih dari sekedar pertemanan dan menurut anak maupun orang tua mereka sama sama suka artinya mereka sudah siap dinikahkan karena jodohnya sudah datang. Ketika kesimpulan terhadap situasi hubungan anak seperti ini, maka menikah dianggap sebagai jodoh yang sudah ditakdirkan oleh Yang Maha Kuasa dan umur menjadi pertimbangan yang kesekian.

Pemahaman yang lain adalah apabila ada yang melamar (meminang) anak gadis dan anak gadis tidak sedang sekolah dan menurut pertimbangan orang tua pernikahan 
merupakan jalan yang terbaik, maka situasi ini juga diterjemahkan bahwa jodoh sang gadis sudah datang. Pemahaman terhadap melamar (meminang) dalam perspektif masyarakat desa di kabupaten Seluma harus diletakan dalam kerangka bahwa keluarga dan anak sudah saling mengenal. Artinya tidak ada proses melamar/meminang selama ini yang terjadi secara tiba-tiba tanpa didahului setidaknya saling mengenal kedua orang tua. Dalam konteks ini dapat terjadi anaknya tidak saling mengenal akan tetapi hubungan kedua keluarga sudah dekat dan baik (perjodohan) yang motif dibalik perjodohan bervariasi dari beberapa kasus pernikahan anak yang terjadi.

Dalam diskusi kelompok terungkap bahwa kearifan lokal sering menjadi pemicu terjadinya pernikahan anak di kabupaten Seluma meskipun tindakan yang "pemaksaan perkawinan" berdampak tidak menguntungkan kehidupan anak. Secara ekonomi konsekuensi tindakan orangtua ini, orangtua akan menanggung kebutuhan ekonomi anak, anak akan hidup bersama satu rumah dengan orang tua dan membantu pekerjaan orangtua. Artinya bagi anak tidak ada ketakutan untuk tidak hidup layak pada umumnya sesuai dengan standar desa. Akan tetapi dari aspek lain seperti psikologis, pendidikandan kebutuhan interaksi sosial anak akan terganggu. Dalam banyak literatur pernikahan anak di negara berkembang dianggap salah satu faktor yang merugikan dan merampas kehidupan sosial dan ekonomi masa depan jutaan anak (Malhotra, 2010).

\section{e. Internet dan Pergaulan Bebas}

Perkembangan internet masuk desa yang diharapkan dapat menambah wawasan pengetahuan dan meningkatkan kecerdasan masyarakat desa ternyata tidak selamanya berjalan linier seperti yang diharapkan. Internet tidak saja membawa dampak positif akan tetapi dampak negatif yang ditimbulkan sama besarnya dengan maanfaat yang dirasakan. Masuknya internet dikalangan remaja pedesaan telah memberi akses yang mudah bagi para remaja mengkonsumsi situs-situs porno.Situs situs seperti inilah yang telah berkontribusi mempercepat pendewasaan anak kaitannya dengan hal-hal yang berbau pornografi seperti hubungan intim.Tidak diimbanginya pendidikan tentang kespro (kesehatan reproduksi) dan moral agama serta lemahnya kontrol orangtua dan masyarakat menjadi penyebab anak-anak menjadi cepat dewasa dan terperangkap hubungan diluar nikah.Meskipun pemerintah telah berusaha dengan keras untuk memblokir situs-situs seperti itu, faktanya tidak seratus persen berhasil.Hal demikian 
karena sangat banyaknya situs situs yang bermuatan materi pornografis baik yang legal maupun illegal bertebaran di dunia maya. Sebagai contoh menurut kementrian Informasi dan Komunikasi bahwa pada tahun 2016, kantor kementrian Informasi dan Komunikasi telah memblokir sekitar 774 situs yang berisi konten pornografi. Lebih jauh, kebanyakan mereka yang terpapar berdasarkan hasil penelitian adalah para remaja baik SMP maupun SMA (Gunarsah, 2004).

Banyak kasus perkawinan anak terjadi karena pergaulan bebas sang anak sehingga menyebabkan anak hamil sebelum menikah. Seperti telah dijelaskan sebelumnya, bagi masyarakat di Sukaraja perbuatan sex bebas ini sangat dikecam dan diharamkan, sehingga apabila anak gadis sudah hamil sebelum menikah maka tidak ada pilihan dalam pandangan orangtua untuk dinikahkan bukan untuk digugurkan karena menurut ajaran agama pengguguran janin merupakan perbuatan dosa besar.

Maraknya penggunaan smartphone yang bisa akses internet juga telah mengkhawatir sebagian besar orangtua. Orangtua sangat menyadari bahwa mereka susah untuk mengontrol penggunaan HP karena kebanyakan orangtua gagap dengan pengoperasian HP smartphone. Melarang anak untuk tidak menggunakan HP menurut mereka juga bukan tindakan yang bijak ditengah era teknologi modern. Remaja yang tidak memiliki HP digolongkan sebagai "kampungan" atau "jadul (jaman dulu)" dan klaim seperti ini sangat dihindari oleh para remaja dewasa ini termasuk di Kabupaten Seluma.

Keberadaan internet dan berbagai aplikasinya bukanlah faktor utama.Namun media sosial dapat sebagai pemicu, termasuk adanya masyarakat yang terpaksa menikahkan anak gadisnya dibawah umur karena menghadapi fakta anaknya sudah hamil 3 bulan.Orangtua menyadari sepenuhnya kebutuhan informasi dan tuntutan pergaulan anak-anak zaman sekarang (anak zaman now).Oleh karena itu dia memfasilitasi anaknya dengan membelikan Hand Phone. Lebih jauh sebenarnya keberadan HandPhone (HP) lebih untuk melancarkan hubungan komunikasi dengan anaknya mengingat jarak yang jauh dari tempat tinggal anak dan tempat ia kerjanya. Diluar perkiraannya bahwa maksud yang baik tersebut berdampak masalah bagi anak gadisnya.Sebagai orangtua dia tidak bisa berbuat apa-apa karena orangtua juga ikut andil dengan tidak mengawasinya dengan baik dikarenakan bekerja jauh diluar desa.Dari sisi orangtua sebenarnya tidak berharap dan tidak ingin perkawinan ini terjadi 
pada anak gadisnya yang masih umur 15 tahun karena saat itu dia masih duduk di bangku SMP.Sang pacar yang juga dikenal oleh orangtua tidak melanjutkan sekolah setelah tamat SMP.Dia bekerja membantu orangtuanya di kebun. Faktor sang pacar yang tidak sekolah dan merasa sudah bekerja inilah, menurut orangtua si gadis menjadi pemicu terjadinya hubungan sex pra nikah.

\section{KESIMPULAN}

Dari hasil kajian terhadap faktor-faktor yang mendorong terjadinya pernikahan anak di Kabupaten Seluma dari perspektif para tokoh formal maupun informan dan masyarakat pada umumnya dapat disimpulkan bahwa faktor yang melatarbelakangi terjadinya pernikahan anak di kabupaten seluma cukup kompleks yang melibatkan faktor internal individu maupun faktor eksternal seperti kemiskinan keluarga, terbatasnya pengetahuan orangtua dan anak terhadap dampak pernikahan anak maupun pengaruh faktor ekternal seperti mudahnya akses internet, kurang ketatnya pengawasan lingkungan sosial masyarakat. Kompleksnya dimensi yang melatarbelakangi pernikahan anak menuntut diperlukan kebijakan formal yang integratif lintas sektor dan keterlibatan tokoh adat dan masyarakat guna menghindari perkawinan anak serta pada level keluarga perlu peningkatan pengetahuan orangtua dan anak secara komprehensif terkait dengan pendidikan kesehatan reproduksi (Kespro). Tidak ada penyelesaian tunggal terhadap masalah pekawinan anak di dunia (Girls Not Brides, 2014). Kerjasama lintas sektor dan pemahaman yang benar terhadap penyebab dan dampak pernikahan anak baik pada level institusi formal pemerintah, institusi sosial tingkat desa, lingkungan sosial, orangtua dan remaja diharapkan akan berdampak positif bagi upaya penmencegah pernikahan anak secara arif di kabupaten Seluma.

\section{DAFTAR PUSTAKA}

Ariefuddin, A. 2016, "Problem Perkawinan Anak di Indonesia", http//www.qureta.com/perkawinan anak, diakses 28 April 2016.

Baker,N. 2016. "Masa Kecil yg tercuri:Pengantin Anak di Sulawesi Barat, Unicef Indonesia, Jakarta.

Bappeda Seluma, 2014. "Penanggulangan Kemiskinan Kabupaten Seluma",TNP2K, Kab. Seluma. 
Bappenas RI, 2008, Laporan Pencapaian MDG”s 2008, Bappenas, Jakarta.

BKKBN, 2014. "Profil Kependudukan dan Pembangunan Provinsi Bengkulu ", BKKBN Provinsi Bengkulu.

BKKBN, 2015, "Pendataan Keluarga 2015”, BKKBN Provinsi Bengkulu.

BPS Seluma. 2013. “Seluma Dalam Angka (2013)”. BPS Kabupaten Seluma.

BPS. 2016. Survey Ekonomi Nasional 2016, BPS RI,Jakarta.

BPS. 2013. Survey Ekonomi Nasional 2013, BPS RI,Jakarta.

Bungin, Burhan. 2005. “Analisis Data Penelitian Kualitatif”. Raja Grafindo Persada, Jakarta.

Gee,E. M. 1994. "The Family" in Robert Hagedorn, Sociology, Holt, Rinehart and Winston Canada Lmt., Canada.

Girls Not Brides.2014. Brook Green, “A Theory of Change on Child Marriage”, First floor, London, UK.

Grijns,M.2014." Child Marriage in Indonesia as Hidden Injustice”, Van Vollenhoven Institute, Leiden Law School, Java Village Foundation.

Gunarsah, S.D.2004.” Dari Ananak sampai Usia Lanjut: Bunga Rampai Psikologi Anak", BPK Gunung Mulia, Jakarta.

Hagedorn, R., 1990, Sociology, 4th edition, Holt, Rinehart and Winston of Canada, Limited, Toronto.

ICRW, 2005, “Analysis of Demographic and Health Survey (DHS) Data, Most Recent Survey for All DHS Survey Countries, New York.

ICRW. 2014.“ Too Young to Bed: Education and Action Toward Ending Chil Marriage", New York.

Kabupaten Seluma. 2018. Kabupaten Seluma dalam Angka 2018, BPS Kabupaten Seluma, Bengkulu.

Kemenenterian Kesehatan.2010. Laporan Riset Kesehatan Dasar 2010, Kemenkes RI, Jakarta. 
Kementrian Pendidikan dan Kebudayaan.2016. Analisis Kerja Pendidikan Provinsi Bengkulu,Pusat data dan Statistik Pendidikan, Jakarta.

Maholtra, Anju.2010, "The Couses, Consequences and Solutions to Forced Child Marriage in the Developing World", ICRW, Washington D.C.

Nasrin, S.E dan Rahman, KM. 2012.“ Factora Affecting Early Marriage and Early Conception of Women: A Case of Slum Areas in Rajshahi City Bangladesh", International Journal of Sociology and Anthropology Vol. 4(2), pp 54-62, February 2012.

Poloma, M.2000, Sosiologi Kontemporer, Terjemahan, P.T.Raja Grafindo Persada, Jakarta.

Ritzer, G and D.J. Goodman. 2008. Modern Sociological Theory, 7th edition, McGrawHill Higher Education, New York.

Ritzer, G. 1980. Sociology: A Multiple Paradigm Science,'Sosiologi Ilmu Pengetahuan Berparadigma Ganda disadur oleh Alimandan",Penerbit C.V. Rajawali, Jakarta.

Sah, R.B et al. 2014. "Factors Affecting Early Age Marriage in Dhakunta Municipality, Nepal", Nepal Journal of Medical Sciences, Volume 03, Number 1, JanuariJune, pp. 26-30.

Kabupaten Seluma Dalam Angka 2004-2014.

Singh, S. And Samara, R. 1996. "Early Marriage Among Women In Developing Countries”,International Family Planning Perspectives, 22:148-157 \& 175.

Todaro, M and S.C. Smith, 2003, Economic Development, 8th edition, Pearson Education Limited, United Kingdom.

UNFPA, 2016.”Child Marriage",http//www.Unfpa.org/child marriage. Diakses 28 April 2016.

Unicef. 2001. "Early Marriage: Child Spouse", Unicef Italy, Florence Italyevelopment

Unicef. 2005, Early Marriage: A Hrmful Traditional Practice, New York

Unicef. 2014.”A Atudy On Early Marriage in Jordan”, Unicef Jordan, Aman.

Unicef. 2015,"AJI-UNICEF Media Awards 2015”, http://www.unicef.org /indonesia/id/media_24994.html, diakses 28 April 2016.

Usaid. 2012.'Endeing Child Marriage and Meeting The Needs of Married Children: The Usaid Vision For Action", US Agency for International DAID. 
Wood, Charles. 1981. "Structure Changes and Household Strategy: a Conceptual Framework for the Study of Rural Migration", Human Organisation, Vol.40, No. 4, pp. 338-44.

WPF. 2013. "World Fertility Report 2012”, United Nation, Departemen of Economic and Social Affair, Population Division, LA. 